

\title{
OF TIME AND THINGS: USES OF OBJECTS FROM SOVIET MASS GRAVES
}

François-Xavier Nerard

\section{To cite this version:}

François-Xavier Nerard. OF TIME AND THINGS: USES OF OBJECTS FROM SOVIET MASS GRAVES. Les Cahiers Sirice / Irice, 2017. hal-01895630

\section{HAL Id: hal-01895630 \\ https://hal-paris1.archives-ouvertes.fr/hal-01895630}

Submitted on 15 Oct 2018

HAL is a multi-disciplinary open access archive for the deposit and dissemination of scientific research documents, whether they are published or not. The documents may come from teaching and research institutions in France or abroad, or from public or private research centers.
L'archive ouverte pluridisciplinaire HAL, est destinée au dépôt et à la diffusion de documents scientifiques de niveau recherche, publiés ou non, émanant des établissements d'enseignement et de recherche français ou étrangers, des laboratoires publics ou privés. 


\section{OF TIME AND THINGS: USES OF OBJECTS FROM SOVIET MASS GRAVES}

François-Xavier Nérard

UMR Sirice | « Les Cahiers Sirice»

2017/2 N 19 | pages 77 à 92

ISSN 1967-2713

Article disponible en ligne à l'adresse :

https://www.cairn.info/revue-les-cahiers-sirice-2017-2-page-77.htm

Pour citer cet article :

François-Xavier Nérard, « Of time and things: uses of objects from Soviet mass graves », Les Cahiers Sirice 2017/2 (N¹9), p. 77-92.

Distribution électronique Cairn.info pour UMR Sirice.

(C) UMR Sirice. Tous droits réservés pour tous pays.

La reproduction ou représentation de cet article, notamment par photocopie, n'est autorisée que dans les limites des conditions générales d'utilisation du site ou, le cas échéant, des conditions générales de la licence souscrite par votre établissement. Toute autre reproduction ou représentation, en tout ou partie, sous quelque forme et de quelque manière que ce soit, est interdite sauf accord préalable et écrit de l'éditeur, en dehors des cas prévus par la législation en vigueur en France. Il est précisé que son stockage dans une base de données est également interdit. 


\title{
Of time and things: uses of objects from Soviet mass graves
}

\author{
François-Xavier NÉRARD
}

On July 1, 1943, Maria Mikhailovskaya arrived in the provincial capital city of Vinnitsa in central Ukraine. She had travelled from the village of Sokolovka, some seventy kilometres north, in the hope of receiving some news about her husband, Albin. He was a collective farmworker who had been arrested by the Soviet secret police, the NKVD, six years before on November 18, 1937. Entering a former orchard, almost two kilometres north of the city, she would have seen that the ground had been dug up in several places, and she would have heard the voices of the Polish and Soviet prisoners of war as they continued to dig. The smell would have been dreadful. Dozens of decaying corpses lay alongside the mass graves in which they had formerly been buried. It is hard to imagine what she must have been feeling. The German officials took her to where many different coats were hung up between the trees. Other wives of former prisoners were there too. Like her, they wandered between the corpses and the clothes trying to find traces of their loved ones, their husbands, brothers, sons. Suddenly, Maria stopped. That striped satin jacket lining was unmistakable. It had to be Albin's jacket, the one he had been wearing on the day of his arrest. The following day, on July 2, with the help of an interpreter, she testified before a German judge. There were 468 people in all who managed to recognise a piece of clothing that had belonged to a loved one who had been arrested and shot during Stalin's Great Terror. ${ }^{1}$

The role played by the objects unearthed from the Stalinist mass graves was crucial in Maria Mikhailovskaya's case. The object (i.e. the jacket) directly linked the past (her husband's arrest and subsequent disappearance) and the present (unrecognisable decaying corpses). This paper will focus on these powerfully evocative material traces of the Vinnitsa massacre and on those from several other mass gravesites unearthed in the former Soviet Union (in

1 Amtliches Material zum Massenmord von Winniza, Berlin, Zentralverlag der NSDAP, Franz Eher Nachf, 1944, p. 261-262. 
the Urals in 1919 and in Voronezh and Moscow after 1989). It will assess their role, uses, and functions during the exhumation processes in the Soviet Union. I will argue that this role varied considerably over time. In other words, the fresher the graves, the less attention was paid to the objects, and conversely the greater the time lapse between the massacre and the excavation of the graves, the greater the significance of the objects and the more redefined they became. The interpretation of these objects also necessarily changed with the viewer. A victim's relative did not have the same relationship with them as an archaeologist or a historian did. The story I am going to tell is therefore a deeply historical one. It is a story of time and objects.

\section{Decisive factors in Soviet Union exhumations}

What happened to Maria Mikhailovskaya was extremely out of the ordinary. Mass graves during the 20th century in the former Soviet Union were certainly not uncommon. Wars, famines, political confrontation, and repression brought with them millions of victims, who were often buried in collective graves. Exhumations were (and still are) very rare, however. Most of the victims of political violence on Soviet soil remain buried. Nevertheless, it is possible to distinguish three different periods when the exhumations of political mass graves were carried out. The first took place in the immediate wake of the Civil War (1918-1921) when the Bolsheviks tried to open up the mass graves of their fallen comrades in order to honour and rebury them. They also wanted to document the extent of the White Terror. The second came with the Nazi occupation of the western side of the USSR. ${ }^{2}$ The Germans were looking for proof of the violence committed by what they claimed was "JudeoBolshevism." The third and longest period began at the end of the 1980s with Mikhail Gorbachev's perestroika. The desire to expose Stalinist crimes and learn the truth mobilised Soviet citizens and political activists to find the mass graves of the Great Terror and investigate them. Excavations have also been carried out in recent years, such as in Saint Petersburg (2010-20133) on a site

2 Exhumations were also organised in order to document the Fascist atrocities after the Germans' defeat by Soviet authorities (mainly the Extraordinary State Commission). See Nathalie Moine, "La commission d'enquête soviétique sur les crimes de guerre nazis: entre reconquête du territoire, écriture du récit de la guerre et usages justiciers," Le Mouvement Social, 222, 1, 2008, p. 90.

3 See, for example, the report in the weekly paper, Argumenty $i$ fakty: http://www.aif.ru/society/history/naydennye_v_peterburge_ostanki_zhertv_krasnogo_te rrora_ne_mogut_zahoronit, accessed October 1, 2017. 
next to the Peter and Paul Fortress dating back to the Civil War era. It must be stressed, however, that no systematic work has ever been engaged in, and only a few (less than a dozen) graves were actually investigated over the course of the 20th century.

In each of these periods, the contexts of the exhumations were all highly political, albeit in very different ways. After their victory in a very bloody Civil War, the Bolsheviks were looking for their fallen comrades so that they could count and then honour them. The communist fighters shot by the Kolchak police in Tomsk in March 1919 were, at first, thrown into a mass grave in the city's Tatar cemetery. After the Bolsheviks reconquered the town, their bodies were exhumed and reburied in the centre of the city at the Place of the Revolution (now called Sobornaya Plochtchad), and a monument was erected to commemorate their sacrifice. 4

The Nazis' political agenda was even more manifest because they were hoping their discoveries would have a huge impact in terms of their antiSoviet and anti-Semitic propaganda. Stalinist violence was of little consequence to them. They themselves had created mass graves in Vinnitsa, killing and burying almost the entire Jewish population of the city, accounting for 33,150 people in 1939, which was more than a third of the overall population $\left(93,032^{5}\right)$. The main location searched by the Nazis in the USSR was Katyn Forest, where the NKVD had massacred Polish prisoners of war in March-April 1943.6 Several other burial sites were also excavated, including Bykovnia,7 near Kiev and, of course, Vinnitsa ${ }^{8}$. Politically motivated, these excavations were used for propaganda purposes. The mass graves were held

4 On this monument, see http://memorials.tomsk.ru/memorials/bratskaya-mogilabolshevikov-podpolschikov-173.html, accessed October 2, 2017.

5 http://www.demoscope.ru/weekly/ssp/ussr_nac_39_ra.php?reg=2. The Germans entered the city on July 19, 1941. Most of the Jews were killed in the September. See F. Vinokurov, "Evrei Vinnicy v period nacistskoj okkupacii 1941-44 g" [Jews in Vinnitsa during the Nazi occupation 1941-44], Materials of the international conference Jews of Ukraine: history and present, Zhitomyr, 2009, p. 401-414.

6 On these events, see Kosicki Piotr H., The Katyń Massacres of 1940, Online Encyclopedia of Mass Violence, [online], published on 8 September, 2008, accessed 04/10/2017, http:/ / www.sciencespo.fr/mass-violence-war-massacre-resistance/en/document/katynmassacres-1940, ISSN 1961-9898

7 See the article written by Yuri Shapoval in the current issue.

8 On the war in Vinnitsa province, see Amir Weiner, Making sense of War: The Second World War and the fate of Bolshevik Revolution, Princeton, Princeton University Press, 2001, 416 p. (on the exhumations, p. 264-271). See also Irina Paperno, "Exhuming the Bodies of Soviet Terror," Representations, 75, 2001, p. 89-118. 
up as the key massacre sites of the so-called Jewish Bolsheviks against the Ukrainians and were exploited by the German propaganda machine. Images of Ukrainian women looking for their loved ones became a major feature of Nazi propaganda in the wake of the Katyn exhumations. Earlier on the same year, such images had been used in a number of posters (fig. 1). The results of the Vinnitsa investigations were also published in German in 1944 by the NSDAP official publishing house (Zentralverlag der NSDAP) under the title Amtliches Material zum Massenmord von Winniza (official materials on the mass murders of Vinnitsa ${ }^{9}$ ).

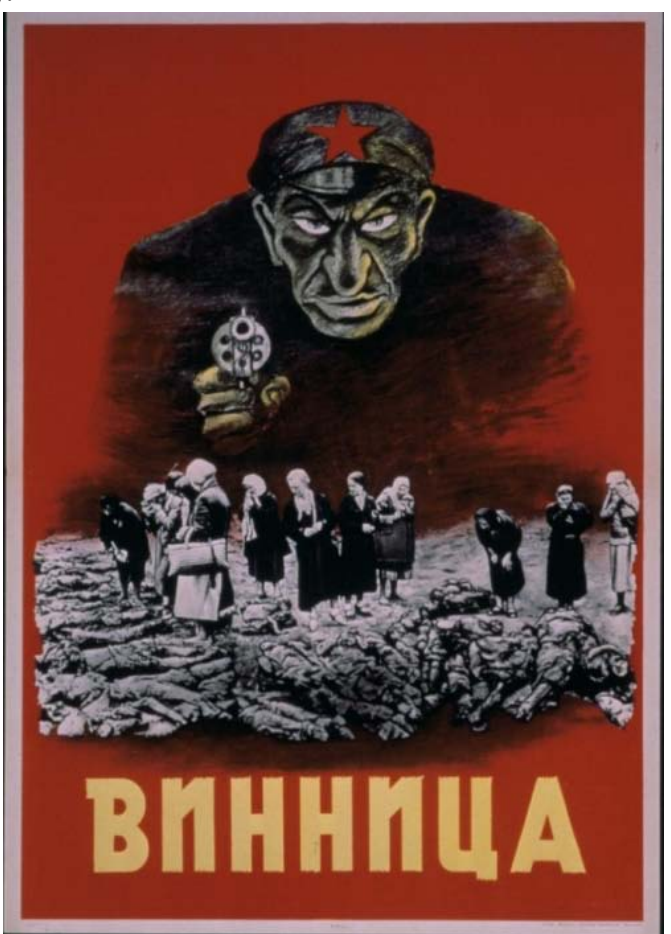

“German propaganda poster," unknown artist, 1943 @ Courtesy of the United State Holocaust Memorial Museum

9 This book was translated into English in 1989 by the Ukrainian Historical Association of North America under the supervision of Ihor Kamenetsky, a Professor Emeritus at Central Michigan University. He decided, however, to "omit" almost all mention of antisemitism in the translation. Ihor Kamenetsky, The Tragedy of Vinnytsia: materials on Stalin's policy of extermination in Ukraine during the great purge, 1936-1938, Toronto; New York, Ukrainian Historical Association in cooperation with the Bahriany Foundation and the Ukrainian Research and Documentation Center, 1989. On the omissions, see Irina Paperno, "Exhuming the Bodies...," art. cit., p. 100-101. 
Some 40 years later, activists with a very different, albeit still political, purpose were trying to locate the Stalinist mass graves. Their aim was to uncover the "great secret ${ }^{10}$ " of the Stalinist Great Terror. During the Great Terror (1937-38), people were arrested, mostly at night, and then they literally disappeared. Their relatives were never told their real fate, which was that they were shot. Instead, the official line was that they had been sentenced to "ten years of corrective labour camps without the right of correspondence." Even during the Krushchev thaw, the Soviet authorities forged imaginary causes of death for the rehabilitated victims. The first gravesites were discovered in Kuropaty, ${ }^{11}$ near Minsk, where "selective exhumations" had been carried out in July and November 1988. This had a huge impact on the rest of the Soviet Union, and many different mass gravesites, "local Kuropaty", were then located thanks to the efforts of political activists, who were encouraged by the initial successes of their Belarusian counterparts. Most of the time, establishing the precise position of the graves was considered sufficient in itself, and no excavations were carried out (the explanations given for this ranged from lack of resources to religious arguments). Exceptions ${ }^{12}$ to this included the exhumations carried out in Dubovka near the city of Voronezh in central Russia during the summer of 198913 and those at the Butovo site in the southern suburbs of Moscow in August 1997 (this latter site was discovered in October 199314). There was, however, less of a focus on the political exploitation of exhumations in these cases, but they certainly contributed to public knowledge of the truth. While some monuments were erected, these sites principally became places of mourning for the relatives.

Most of these exhumations were carried out in a relatively amateur fashion. With a significant lack of resources, they were far from meeting the usual

10 François-Xavier Nérard, "The Great Secret: Sites of Mass Killings in Stalinist Russia," in Philip G. Dwyer \& Lyndall Ryan, Theatres of violence: massacre, mass killing, and atrocity throughout history, New York, Berghahn Books, 2012, p. 186-198.

11 For an initial study of that case, see David R. Marples, "Kuropaty: The Investigation of a Stalinist Historical Controversy," Slavic Review, 1994, p. 513-523.

12 Bykovnia, near Kiev, was a very peculiar case, where exhumations took place several times. See Yuri Shapoval's article in this issue.

13 Akin'shin A. N., Bitjuckij V. I., Lasunskij O. G. and Nikolaev K. B., Politicheskie repressii v Voronezh: putivoditel' [political repressions in Voronezh: a guide], Krasnojarsk, PIK "Ofset", 2011.

14 François-Xavier Nérard, "La mémoire de Boutovo, massacres de masse des années trente en Russie soviétique," in Luc Buchet \& Isabelle Séguy (eds.), Vers une anthropologie des catastrophes: Actes des 9e journées d'anthropologie de Valbonne, Antibes, Éditions apdca, 2008, p. 143-159. 
forensic investigation standards. In Kamyshlovo in August 1919, for example, the works were carried out by a small team (five people) under the supervision of a certain Khokhryakov, who was a communist and a member of the Revolutionary Committee. The only "scientist" present was Zuev, a medical attendant (feld'sher). All the others were communist activists. ${ }^{15}$ The team "exhumed, made a medical examination of and buried the victims of the white guards' bands ${ }^{16}$." This laconic sentence gives a sense of the speed with which the whole process was performed. This kind of improvisation can also be found in the operations carried out at the end of the 20th century, which were mostly organised on a militant basis. In Dubovka, most of the team was made up of volunteers, including museum workers and students, who were generally looking for World War II graves. Igor Paranekhvich was a judicial expert. Competent specialists were, however, involved in the Butovo exhumations in 1997, including archaeologists (Yuri Smirnov, a fabric specialist, and Anatoli Razumov), anthropologists (G. Romanova), and museum workers (Tatiana Alechina, who was working for the State historical museum, and V. Prokopov, a collaborator from the Armed Forces Museum ${ }^{17}$ ). Nevertheless, these specialists took part in the excavations on a purely voluntary and essentially militant basis, and nothing was really organised. Indeed., there has never been any systematic effort nor any real scientific exhumation campaign.

The only exception to this was the 1943 operations in Vinnitsa. The Germans put vast human and technical resources into carrying out these exhumations. They were led by Professor Gerhard Schrader, director of the Institute of Forensic Medicine and Criminal Investigation at the University of Halle-Wittenberg. He was assisted by two fellow academics (Dozent), Joachim Camerer and Dr Volland, as well as by a dissector from Halle called Karl Lentsch and Ukrainian specialists Professor Ivan Malinin (University of Krasnodar ${ }^{18}$ ) and his assistant Arkhip Doroshenko. An international

15 Center for documentation on public organisations for the Sverdlovsk Province (CDOOSO), f. 41, inv. 1, d. 126, p. 114.

16 Ibid.

17 "Issledovanija poslednyh let na butovskom poligone" [The research in recent years on the Butovo Polygon], in L. Golovkova et alii (eds.), Butovskij Poligon, 1937-1938. Kniga pamjati žertv političeskih repressij [Butovo's Polygon, 1937-1938. Book of memory of the victims of political repression], Moscow, Alzo, tome 3, 1999, p. 8.

18 On the fate of Ivan Malinin, see Marina Ju. Sorokina, "Mezh dvukh diktatur: sovetskie uchenye na okkupirovannyh territorijah SSSR v gody Vtoroj mirovoj vojny (k postanovke problemy)" [Between two dictatorships: soviet scientists in the occupied territories of the USSR during the Second World War - issues and problems], Ежегодник Дома русского 
Commission of Foreign Medical Examiners, made up of scientists from eleven countries (including Dr Maurice Duvoir, Professor of Forensic Medicine at the Université de Paris), also worked at Vinnitsa ${ }^{19}$. As a result, these were probably the most professional exhumations carried out in the whole of Soviet and Russian history, albeit they were not exempt from certain biases mainly on account of their highly political agenda involving an overtly anti-Semitic interpretation.

All the mass graves had been dug in the decades following the October Revolution. In the Urals, they resulted from the Civil War, where a large number of people were killed during the retreat of the Koltchak army in 1919. The Stalinist Terror took place between the end of July 1937 and November 1938. While the mass graves exhumed in 1919 were opened just a few weeks after the killings had taken place, the time interval between the creation and exhumation of the Kamyshlovo, Vinnitsa, and Butovo mass graves differed considerably. In these latter cases, the interval was up to five or six years for the 1943 exhumations and more than half a century for the exhumations conducted at the end of the 1980s. The opening of the graves therefore took place in very different contexts, both politically and technically. The time lapses are of huge importance here.

All three factors discussed above, namely political agendas, different levels of professionalism, and time intervals, had a great influence on the way in which the objects found in mass graves were dealt with and interpreted.

\section{Objects and Victims}

One of the central motives in exhuming these mass graves was to establish the identity of the people who had been killed, in other words to know who were in the graves. After the Civil War, most of the archives in the Urals relating to the mass graves comprise lists of names ${ }^{20}$ (with estimations of age, descriptions of causes of death, and lists of wounds). The German record of the excavation in Vinnitsa also includes lists of names. ${ }^{21}$ During perestroika,

зарубежья им. Александра Солженицына [Annual journal of Aleksandr' Soljenitsyn's house for Russians abroad], 2012, p. 146-203. Marina Sorokina published an unprinted article written in 1950 by Malinin on his participation in the exhumations, p. 179-203.

19 Amtliches Material..., op. cit., p. 7-8.

20 State Archive for Sverdlovsk Region (GASO), collection 511, inv. 1, d. 235 for example.

21 Amtliches Material..., op. cit., p. 215-248. This is the list of the 679 corpses, identified as of October 7, 1943. 
the compiling of books of memory was a priority for both the activists and the population. These books were filled with names and some minimal biographical information (date of birth, date of arrest, date of execution, reasons for condemnation).22 In August 1919, the Kamyshlovo Bolsheviks exhumed bodies that had probably only been killed a few weeks before. Since most of the bodies were still intact, the procedure of identification was simplified.

"All these corpses were taken out of the graves to examine and photograph, and then they were put on the side of the Siberian Highroad.[...] [for] inspection by the relatives for identification. 23 "

Of the 78 bodies exhumed, 28 were recognised. There was no need for objects here to help in the identification process. Most people were just able to recognise their loved ones. Indeed, the descriptions of the excavation do not even mention any objects but instead focus only on the corpses and their identification.

The situation was somewhat different in Vinnitsa, however, where the bodies lying in the graves had been killed in 1937-38 (i.e. five or six years before the exhumations took place). The state of decomposition of the corpses was therefore very different from that found in the former case. Some of the bodies were actually put on display, as we are told by the Germans:24 "[They lay] exposed to the elements for only a short time for purposes of identification by family members. ${ }^{25}$ " However, only nine out of the total 679 bodies were recognised through this direct observation. Personal objects (called "identification material" [Identifizierungsmaterial] by the Germans) belonging to the victims that were found in the graves played a key role in the identification process and included clothes, shoes, amulets, and medals. Most of the so-

22 See, for example, the collection, Anatoli Ja. Razumov (ed.), Leningradkij Martirolog, 1937-1938 [The Leningrad martyrology, 1937-1938], 13 tomes, Saint-Petersburg, Rossijskaja Nacional'naja Biblioteka, 1997-2014. Online research is possible: http://visz.nlr.ru, accessed July 21, 2017.

23 CDOOSO, f. 41, inv. 1, d. 126, p. 114-122.

24 Ivan Malinin claims that the exhumations began without German authorization on May 10. The German commission arrived in the city on June 15, and the international commission arrived in the August. During the month of the "autonomous" Ukrainian excavations, objects had obviously already been found. According to Malinin, these were exhibited "on the main street of the city". No other testimonies confirming this assertion were found, however.M. Sorokina, art. cit., p. 192, 196, 197.

25 Amtliches Material..., op. cit., p. 124 [Kamenetsky, p. 145]. All English quotations have been taken from Kamenetsky's translation. Where necessary, both references have therefore been given (i.e. German original followed by the translation in brackets). 
called "identified" corpses had not therefore strictly speaking been identified. As in the case of Maria Mikhailovskaya and her husband's jacket, objects that were linked to concrete individuals served to identify the bodies. However, the link between the object and the corpse was not always obvious unless the object was still on the body, which was often far from the case.

In Vinnitsa, as well as in Voronezh and Butovo, thick layers (between 30 and $40 \mathrm{~cm}$ ) of clothing and other objects were found lain on top of the corpses. ${ }^{26}$ There were also a number of special pits where only objects were found (including three in Vinnitsa). While it is possible these objects were the victims' belongings that had been confiscated upon arrest, it is more likely they were objects that had been brought to the prisoners by their family members but had never been passed on to them (either due to the guards' carelessness or because the prisoners had already been executed. Because people were not told about these executions, they kept transmitting packages to their relatives containing clothes and food, which were ultimately thrown away ["In between lay several small packages continuing toilet utensils or tobacco or some food as well27."])

These objects, as we have seen in the Maria Mikhailovskaya case, were put on display at the excavation site, with special attention given to those that stood out and which may have helped with identification:

"Concerning monograms or other personal markings on the apparel - shirts, underwear, and the like - such apparel was hung out between the trees with particular care and in this way made accessible to the public for identification purposes28."

Objects that did not help in the identification process immediately lost almost all their value. Some of these were sent to Germany for further analysis, but nothing is known about their fate after that.

These same piles of clothes have been found in Boutovo and Dubovka, but their value and the uses made of them were totally different. More than fifty years on from the massacres, there were hardly any relatives left alive to recognise these artefacts, which were moreover often in a poor state of preservation. However, over time, these objects have become interesting in themselves, as a testimony of the times of the massacres and a link between the past and the present. They have lost their individual dimension and gained a symbolic quality. For example, rubber overshoes (galochki) with the 1935 brand

26 For Butovo, see Issledovanija..., op. cit., p. 5-16.

27 Amtliches Material..., op. cit., p. 17 [Kamenetsky, p. 100].

28 Ibid., [Kamenetsky, p. 101]. 
seal of the "Krasny Bogatyr" factory (Red Giant ${ }^{29}$ ) were considered a sign of the past and presented as such in books on the excavations.

Miraculously, preserved pieces of paper were also found and used for identification purposes. These were documents often produced by the perpetrators but which directly linked to the victims, such as orders to arrest, search warrants, and search minutes. There were more than 200 of them found in Vinnitsa ${ }^{30}$ in addition to the small number found in Moscow and Voronezh. For example, a wallet was unearthed on September 30, 2007,31 containing part of a NKVD search report. The combined efforts of a legal expert and a local archivist established that this was a copy of a search report that had been established on November 6, 1937, the date of the arrest of Ivan Alexandrovich Dukhovski, a former priest who was shot on December 17, 1937. The consequences of this find was twofold. On the one hand, the publication of this news in newspapers and on the internet allowed the victim's relatives to be found in Slutsk (Belarus) and, on the other, a monument was erected to the 48 people (because the execution report also mentioned 47 other names) assumed to be buried there. 32

Such discoveries were, however, very exceptional. Decades after the killings, the objects recovered were generally of very little help in identifying the victims. Historians and activists have had to turn to other sources, such as archives, to establish the victims' names.

\section{To document and expose}

Alongside the objects belonging to the victims, the graves were also filled with objects linked to the perpetrators (primarily weapons). Objects were therefore helpful in terms of understanding how the victims had been killed. Forensic "specialists" searched for traces of weapons, focusing on sabre wounds in the victims of the Civil War and bullet wounds in the Stalinist Terror victims. Bodies and skulls were examined, with varying levels of meticulousness, to gain a better understanding of the killing techniques. The most striking finding was that traces of weapons were characterised by their relative scarcity. There were almost no cartridges found in the mass graves, which is proof that the people were not killed in the same place that they were

29 See Issledovanija..., op. cit., p. 11.

30 Photos 117 to 126, Amtliches Material..., op. cit., p. 174-188.

31 Politicheskie repressii v Voronezh..., op. cit., p. 147.

32 Ibid., p. 148. 
buried in. The executions probably took place in prisons, and the corpses were then taken for burial on the outskirts of the cities.

When traces of weapons were found, they helped to determine the kinds of weapons used. For example, the 7.62 calibre cartridges found in Butovo ${ }^{33}$ and Dubovka ${ }^{34}$ were variously attributed to a submachine gun (like the Degtariov machine pistol), the Mosin rifle, and even the Nagan pistol. Unfortunately, no precise investigations were ever carried out. The Germans found $.22 \mathrm{~mm}$ diameter bullets. They postulated that these had been fired from a multi-fire handgun, but they did not try to determine the actual weapon, merely satisfying themselves with recording that it was not of German production ${ }^{35}$. The Nazis found "a relatively large number of lead bullets [...] in the remains of the brain ${ }^{36}$ " and carried out a thorough study of the form of the bullets. Their conclusion was that "The type of ammunition had in most cases apparently possessed an inadequate penetrating power, which explains the reason for the several shots fired into individual victims. ${ }^{37 \prime \prime}$ The implication was to denounce the poor quality of Soviet ammunition, even in the process of killing. This leads us directly on to an important aspect of the exhumations, which was to expose Bolshevik crimes.

Objects were also used to show that the Stalinists targeted special groups within the population. The Nazi investigation was overtly anti-Semitic. The whole process was conducted within a Judeo-Bolshevik explanatory framework. Even though the Jewish population had been killed in Vinnitsa when the exhumations began, the aim was nevertheless to hold the Jews responsible in a more global perspective. This was wholly linked to the definition of the victims. They had to be ethnicised and Ukrainised. Hence, of the 679 victims identified, the Germans officially attributed nationality to 490 Ukrainians and 28 Poles. There was no mention of any Jews or Russians even though the urban population of Ukraine in 1937 was heavily Jewish and Russian. ${ }^{38}$ The identification process using witnesses certainly had a major influence on these results because Jews were not able to identify "their" victims anymore. The total absence of Russians is, however, quite surprising.

33 See Issledovanija..., op. cit., p. 14.

34 Politicheskie repressii $v$ Voronezh..., op. cit., p. 130.

35 Amtliches Material..., op. cit., p. 172 [Kamenetsky, p. 153]. This was necessary for the German propaganda as the Soviets were trying to blame the Germans for the massacre.

36 Ibid., p. 33 [Kamenetsky, p. 112].

37 Ibid., p. 85 [Kamenetsky, p. 131].

38 On the propagandic use of this ethnicisation of the dead, see M. Sorokina, art. cit., p. 170-171 and 184-185 (the issue is highlighted by I. Malinin). 
Objects also played a role here. The German excavation report placed a lot of emphasis on the "typical of the area (ortsüblich) ${ }^{39 "}$ " characteristics when describing the clothes found. Photographs show some vyshyvankit0, the typical Ukrainian shirt. Shoes were also mentioned as "specifically, those of sturdy design that, according to people familiar with the area, are for the most part worn in the farming section of the population. 41 " This was an understatement regarding the Ukrainians because they overwhelmingly made up the rural population (whereas Jews accounted only for $2.45 \%$ of the rural population in 1939).

Religious signs (crosses and amulets) found in the graves were presented both in 1943 and in the 1990s $\mathrm{s}^{42}$ as stressing the religious dimension of the repression. These discoveries testify, of course, to the over-representation of priests and believers among the victims. The explicit conclusion of the German authorities was that "A larger number of rosaries, religious amulets, and handwritten religious tracts found among the bodies suggests that a yet much larger number of people were eliminated for adhering to their faith ${ }^{43}$." This is a clear feature of the German discourse in occupied territories at the time.

While crosses were also found in Voronezh, the discourse was different. It was important to show here that the Great Terror had targeted "simple" people, and the crosses were used as evidence of the victims' modest origins, as were the numerous lapti (bast shoes) found: "In 1937-38, it is difficult to assume that these crosses were worn by Soviet employees and, moreover, by party heads! 44 " Incidentally, this observation is far from sound because religious practices were very heterogeneous, and it is well-known that the terror concerned all strata of society at the time. ${ }^{45}$

The objects were also used to draw up a portrait of the perpetrators that emphasised their bestiality, their inhumanity. In Vinnitsa, "tightly twisted handkerchiefs or scarves that had also been rather tightly wound around the

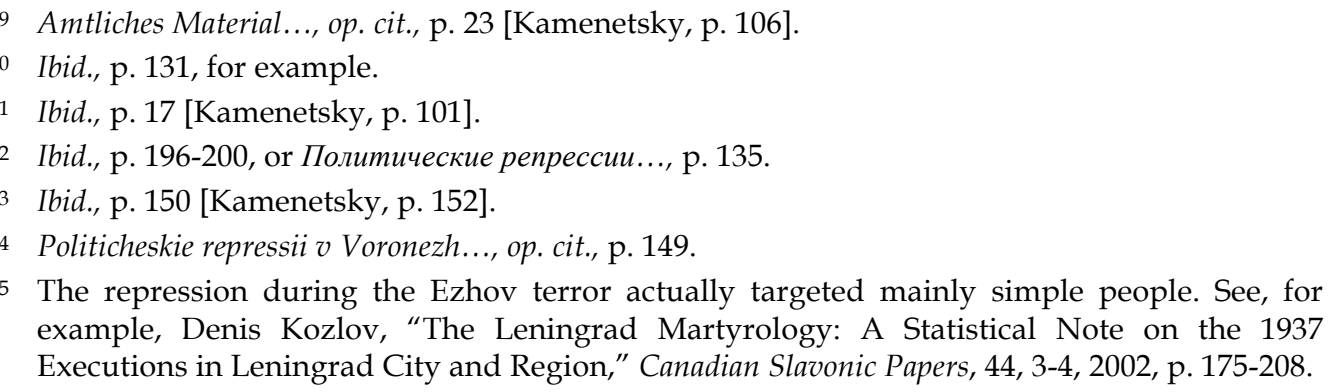

The repression during the Ezhov terror actually targeted mainly simple people. See, for example, Denis Kozlov, "The Leningrad Martyrology: A Statistical Note on the 1937 Executions in Leningrad City and Region," Canadian Slavonic Papers, 44, 3-4, 2002, p. 175-208. 
neck were found on some of the other bodies at the same site.46" The Nazi interpretation proposed that

"the screams of the victims were supposed to have been stifled through an occasional choking of the throat. This assumption, furthermore, is suggested by another means of gagging that has incontestably been established in three cases. Gags of twisted cloth, in this connection, had been stuffed deeply into the mouth and throat."

The report therefore insists on the fact that the "methods employed prior to the shootings had inflicted considerable pain on the victims ${ }^{47}$."

In 2008, some bottles of Zveroboi vodka were found in Dubovka. In the book reporting on the findings of this site, the authors clearly link these bottles with the drinking habits of the perpetrators and even offer the testimony of a former NKVD driver: "After such journeys, I often saw our drivers at the restaurant of the train station. They were drinking. 48 " The photographs of the two bottles are thus presented as "irrefutable proof" that the perpetrators were drinking at the mass graves. The photos' caption further reinforces this message by reproducing Stalin's famous words: "Life has become better, life has become merrier, comrades!" The broken buckets found at Butovo were also linked to the perpetrators' supposed drinking practices. ${ }^{49}$

At Butovo, five gloves were found with the fingers pulled inside out, just as if they had been thrown away. ${ }^{50}$ At all three sites, objects were presented in the published reports to show or tell the horrors associated with the perpetrators. The discourse produced about them was essential. It gave the objects a new dimension since they were used in a symbolic way to show the massacre in its human and personal dimensions in order to provoke a sense of outrage and/or victimisation. With huge chronological variations, photographs play a very important role.

Obviously, we need to pay attention here to the evolution of the political agendas that led to the exhumations. The German project had a clear propaganda agenda. They aimed at provoking outrage and disgust towards the Soviet perpetrators both within Ukraine and in Europe more widely and, in so doing, at weakening the Soviet-Anglo-American alliance. The exhumations, the reports, and the photographs were all used to support these efforts. The meaning of the objects has clearly changed since then. The

46 Amtliches Material..., op. cit., p. 56 [Kamenetsky, p. 124].

47 Ibid., p. 58 [Kamenetsky, p. 125].

48 Politicheskie repressii v Voronezh..., op. cit., p. 155.

49 See Issledovanija..., op. cit., p. 15.

$50 \quad$ Ibid., p. 11. 
emergence of victimhood in the public space and consequently of the way in which we think about the people killed and buried in the mass graves has been a major development over the last few decades. Both during and after perestroika, the Stalinist victims were thought of as pure and innocent. Before perestroika, the emphasis was put on the perpetrators, and after, it was placed on the victims. This switch has had huge consequences. In 1943, there were a lot of often unbearable photographs of corpses. In addition, the Nazis studied, photographed, and published pictures of the ropes used to link the hands and sometimes feet of the prisoners to provoke scandal and revulsion ${ }^{51}$. In the book on the Voronezh exhumations, however, these ropes only received a brief mention. They were not photographed. The respect for the victims had become more important. In contrast, the victims' personal belongings (their spectacles, for example) only received a brief mention in the 1943 reports but were photographed and reproduced in the Voronezh and Butovo reports. Another interesting example is that of the galoshi (rubbers), the plastic overshoes very common in the USSR. While, again, they only received a brief mention in the 1943 report, piles of them were photographed in 2011 in an unmistakable echo of the Auschwitz photographs.

The ways in which the objects found in mass graves have been used has changed considerably over time. They were not even noticed when the mass graves were opened just a few weeks after the massacre, but as the bodies fell apart, the objects associated with them became a very powerful link between the past and the present. The Nazis made substantial use of the objects to promote identification, which fitted in with their propaganda objectives. As the witnesses then disappeared, the objects lost this specificity, this direct link with the dead and the corpses, and their symbolic use came to the fore. They were used to tell and illustrate the stories of the mass graves in books and other publications. At the time of the Nazis' exhumations, the objects were used as political tools, aimed at creating outrage against the perpetrators. In more recent times, however, the objects have been used to arouse sympathy for the victims through moral shock.

The symbolic use of objects is limited, however, and can be frustrating. Forensic archaeology has made immense progress. Exhaustive works on Soviet mass graves could provide a huge quantity of information. For the moment though, the limited quantity of exhumed objects does not allow us to draw any

51 Amtliches Material..., op. cit., p. 54-55. 
firm conclusions. Nevertheless, objects could have helped answer a lot of questions regarding the techniques used in the Terror (from the confiscation of personal belongings to the shootings). After the thousands of pages that have been written on the Great Terror, the killing procedures are still not precisely known.

Who really wants to know about this? Contemporary post-Soviet societies are far less interested in the Stalinist past than Soviet citizens were during perestroika. While the past has not been totally forgotten, it is no longer a burning issue. The direct relatives of the victims have now passed away. The memorialisation of mass gravesites tries to honour the victims through monuments and public signs of grief. The question of how these people were killed now seems to be considered superfluous and even obscene. The time of knowing is already gone, or maybe it is yet to come.

We'd like to thank Clare Ferguson for her careful editing of this article. 